\title{
Cell Response of Calcium Phosphate Based Ceramics, a Bone Substitute Material
}

\author{
Juliana Marchi $^{\mathrm{a} *}$, Christiane Ribeiro ${ }^{\mathrm{b}}$, Ana Helena de Almeida Bressiani ${ }^{\mathrm{c}}$, Márcia Martins Marques ${ }^{\mathrm{d}}$ \\ ${ }^{a}$ Centro de Ciências Naturais e Humanas - CCNH, Universidade Federal do ABC-UFABC, \\ Rua Santa Adélia, 166, Bangu, CEP 09210-170, Santo André, SP, Brazil \\ ${ }^{\mathrm{b}}$ Centro de Engenharia e Ciências Sociais Aplicadas - CECS, Universidade Federal do ABC-UFABC, \\ Rua Santa Adélia, 166, Bangu, CEP 09210-170, Santo André, SP, Brazil \\ ${ }^{\circ}$ Centro de Ciência e Tecnologia de Materiais - CCTM, Instituto de Pesquisas Energéticas e Nucleares - IPEN, \\ Av. Professor Lineu Prestes, 2242, Cidade Universitária, CEP 05508-000, São Paulo, SP, Brazil \\ ${ }^{\mathrm{d}}$ Departamento de Dentística, Faculdade de Odontologia - FO, Universidade de São Paulo - USP, \\ Av. Professor Lineu Prestes, 2227, Cidade Universitária, CEP 05508-900, São Paulo, SP, Brazil
}

Received: April 20, 2012; Revised: November 6, 2012

\begin{abstract}
The aim of this study was to characterize calcium phosphate ceramics with different $\mathrm{Ca} / \mathrm{P}$ ratios and evaluate cell response of these materials for use as a bone substitute. Bioceramics consisting of mixtures of hydroxyapatite (HAp) and $\beta$-tricalcium phosphate $(\beta-\mathrm{TCP})$ powders in different proportions were pressed and sintered. The physical and chemical properties of these bioceramics were then characterized. Characterization of the biological properties of these materials was based on analysis of cell response using cultured fibroblasts. The number of cells attached to the samples was counted from SEM images of samples exposed to cell culture solution for different periods. These data were compared by analysis of variance (ANOVA) complemented by the Tukey's test. The TCP sample had higher surface roughness and lower density. The adherence and growth of FMM1 cells on samples from all groups was studied. Even though the different calcium based ceramics exhibited properties which made them suitable as bone substitutes, those with higher levels of $\beta$-TCP revealed improved cell growth on their surfaces. These observations indicated two-phase calcium phosphate based materials with a $\beta$-TCP surface layer to be a promising bone substitute.
\end{abstract}

Keywords: Bone substitutive materials, calcium phosphate ceramics, cell response

\section{Introduction}

Bone grafting is the most common form of regenerative therapy and has been used for almost 100 years in attempts to stimulate healing of bone defects. Alloplastic bone graft materials are synthetic, inorganic, biocompatible, and bioactive. These bone substitutes are believed to promote healing of bone defects through osteoconduction.

Progress in the field of biomaterials like bioglass, glass-ceramics and calcium phosphate ceramics (such as hydroxyapatite (HAp), $\alpha$-tricalcium phophate $(\alpha$-TCP), $\beta$-tricalcium phophate $(\beta$-TCP) and biphasic mixtures (BCPs)) has been significant in the last few decades ${ }^{1-4}$. The in vitro and in vivo behavior of these ceramics can be influenced by the $\mathrm{Ca} / \mathrm{P}$ ratio, raw material purity, processing variables (such as conformation technique and sintering conditions) and test parameters 5 . The $\mathrm{Ca} / \mathrm{P}$ ratio can result in a material that is resorbable or stable in the human body environment, through a dynamic process involving degradation, reabsorption, phase transformation and cell adhesion ${ }^{1,6-8}$. Often, the best results following extended duration experiments were obtained with biphasic ceramics, considered to have good bioactive properties ${ }^{7,9}$. However, calcium phosphate ceramics with a different $\mathrm{Ca} / \mathrm{P}$ ratio can respond differently in short term tests. Data reported in

*e-mail: juliana.marchi@ufabc.edu.br the literature are results of usually long duration tests and seldom consider responses during the initial stages.

Dissolution of calcium phosphate ceramics degrades its properties affecting formation of the calcium phosphate layer, cell anchorage and the morphological changes in in vitro tests ${ }^{10}$. This is particularly important when the kinetics of the dissolution process of material with varying composition is still unknown. To obtain improved understanding of the interaction between calcium phosphate with different compositions and the DMEM media, the dissolution behavior was determined without any cell approach $^{11}$. However, since calcium phosphate ceramics do not exhibit inert behavior, its characterization through cell culture experiments was carried out ${ }^{12,13}$.

Besides bioactivity or bioinertness ${ }^{14,15}$, other aspects of material-tissue interface interactions are important in the context of biological performance of a biomaterial ${ }^{16-18}$. The composition, purity and roughness of calcium phosphate ceramics affect physical and chemical characteristics, and these in turn influence the biological behavior of these materials. To provide more information to clinicians who wish to use bioceramics as bone substitutive material, this investigation was carried out to determine the biological response of different calcium phosphate ceramics. The in vitro response of FMM1 fibroblasts on high purity 
calcium phosphate ceramics containing different $\mathrm{Ca} / \mathrm{P}$ ratio was determined.

\section{Material and Methods}

\subsection{Characterization of raw material powders}

Commercially available powders of HAp (20-2039 Strem Chemicals, Newburyport, MA, USA) and $\beta$-TCP (21218, Fluka, Buchs, SG, Switzerland) were used. The specific surface area of these powders was determined by the Brunnauer Emmet Teller (BET) method using a Nova 1200 BET Surface Area Analyzer (model 3.11, Quantachrome, Boynton Beach, Florida, USA) and the particle size distribution as well as the mean particle sizes were determined using a laser equipment (Cilas1064, 104, Orléans, France).

\subsection{Sample preparation}

The physical, chemical and biological properties of calcium phosphate ceramics were determined using disks (6.5 $\mathrm{mm}$ in diameter and $\sim 5 \mathrm{~mm}$ high). The disks (50 in number) were prepared as follows: the BCPs powders were mechanically mixed (Turbula-type T2C system, Shatz Willy Abachofen Maschinen, Switzerland) for 2 hours with alumina spheres ( $2 \mathrm{~mm}$ diameter) and deionized water. The five different compositions of calcium phosphate powders (Table 1) were uniaxially pressed (100 MPa), then cold isostatically pressed (200 MPa) and sintered under different conditions (Table 1), depending on TCP:HAp weight ratio ${ }^{19}$. Ten samples of each composition were prepared to permit statistical analysis of the results. The theoretical densities were estimated using the rule of mixtures ${ }^{20}$, assuming $3.07 \mathrm{~g} . \mathrm{m}^{-3}$ for $\beta$-TCP and 3.16 g.cm ${ }^{-3}$ for HAp as their densities.

\subsection{Characterization of Physical and chemical properties}

The sintered calcium phosphate ceramic samples were characterized in terms of their density, surface roughness, phase composition and microstructure, as described below.

The densities of the samples were determined using the Archimedes method ${ }^{21}$. The final densities were expressed as percentage of the theoretical densities.

The surface roughness was measured with a Mitutoyo Surftest 211 portable rugosimeter (Mytutoyo, Japan). The mean surface roughness ' $\mathrm{Ra}$ ' was estimated using 15 measurements, considering five along three different parallel lines.
The crystalline phases were identified qualitatively following X-ray diffraction analysis of samples (Philips X'Pert MD 40, PANalytical BV, Almelo, The Netherlands) with $\mathrm{Cu}_{\mathrm{K}} \alpha$ radiation, $2 \theta$ between $10-60^{\circ}$ at $10^{\circ} \mathrm{min}^{-1}$ at room temperature. The experimental data were compared with JCPDS cards (09-0432 for HAp; 09-169 for $\beta$-TCP and 29-0359 for $\alpha$-TCP).

Gold sputter coated (Sputtering SCD 020, Bal-Tec, Liechtenstein) surfaces of calcium phosphate samples were examined in a scanning electron microscope (SEM, Philips, XL 30, Eindhoven, The Netherlands).

\subsection{Biological response}

The biological response of the calcium phosphate bioceramics with different $\mathrm{Ca} / \mathrm{P}$ ratios was determined by counting cultured cells attached to the top of the bioceramic disks. The cells were cultured and plated on the top of the disks, then, cell adhesion was assessed after 1 day and cell proliferation from 1 to 3 days.

\subsection{Cell culture}

The cells were cultured as previously described ${ }^{22,23}$. Briefly, the FMM1 fibroblasts, a human gingival cell line, were used. These cells were cultured in Dulbecco's modified Eagle medium (DMEM), supplemented with $10 \%$ fetal bovine serum (FBS, Cultilab, Campinas, SP, Brazil) and $1 \%$ antimycotic-antibiotic solution $(10,000 \mathrm{U}$ of penicillin, $10 \mathrm{mg}$ of streptomycin, and $25 \mathrm{mg}$ of amphotericin B per $\mathrm{mL}$ in $0.9 \%$ sodium chloride; Sigma Chemical Company, St Louis, MO). The cells were kept in an incubator at $37{ }^{\circ} \mathrm{C}$ and humidified $5 \% \mathrm{CO}_{2}$ atmosphere. Cultures were supplied with fresh medium every other day. Cells between the $10^{\text {th }}$ and the $14^{\text {th }}$ passages were used in all experimental procedures. The cell culture procedures were done under laminar flow and the tests followed the ISO10993- $5^{24}$.

\subsection{Cell adhesion and proliferation assays}

Sterile ceramic disks of all the experimental groups $(n=45)$ were placed in the bottom of 24-wells cell culture plates (Corning Costar, Cambridge, MA) and covered with DMEM. Then, $10^{5}$ cells were seeded on the top of each disk and the cell culture plates were incubated at $37^{\circ} \mathrm{C}$ in a $5 \% \mathrm{CO}_{2}$ atmosphere. One, 2 and 3 days after seeding, three disks of each experimental group were prepared for SEM examination.

\subsection{Scanning electron microscopy (SEM)}

A SEM was used to observe the surface and to evaluate cell adhesion as well as growth. To observe the surface

Table 1. Characteristics of experimental groups of calcium phosphate ceramics.

\begin{tabular}{ccccc}
\hline ID & \% weight TCP & \% weight HA & $\begin{array}{c}\text { Theoretical } \\
\text { Density }\left(\mathbf{g} / \mathbf{c m}^{\mathbf{3}}\right)\end{array}$ & $\begin{array}{c}\text { Sintering conditions } \\
\text { Temperature/time }\left({ }^{\circ} \mathbf{C} / \mathbf{m i n}^{\prime}\right)\end{array}$ \\
\hline TCP & 100 & 0 & 3.070 & 3.091 \\
25 HA & 75 & 25 & 3.112 & $1250 / 30$ \\
50 HA & 50 & 50 & 3.134 & $1250 / 30$ \\
75 HA & 25 & 75 & 3.156 \\
\hline
\end{tabular}


microstructure, one sample from each experimental group ( $n=5$ disks), without cells was prepared. The scanning electron micrographs ( $n=45$ per group) were used to count the number of attached cells one day after seeding (to determine adhesion) and after 2 and 3 days of seeding (to evaluate growth).

All the samples were fixed with $2.5 \%$ glutaraldehyde in $0.1 \mathrm{M}$ phosphate buffer solution ( $\mathrm{pH} 7.4$ ) overnight at $4{ }^{\circ} \mathrm{C}$ for further SEM studies. Then, the samples were post fixed in $1 \%$ osmium tetroxide in $0.1 \mathrm{M}$ phosphate buffer solution ( $\mathrm{pH}=7.4)$. The samples were then dehydrated in ethanol and chemically dried in hexa methyl disilazane (HMDS, Electron Microscopy Sciences, Fort Washington, PA). The samples were then gold sputter coated before SEM analysis.

\subsection{Cell counting}

Cell counting was done with SEM micrographs of three defined areas of each specimen taken from the same distance $(10 \mathrm{~mm})$ and at the same magnification $(500 \mathrm{X})$. The cells were counted using the Image Pro Plus computational image software ${ }^{25}$. The counting provided data to obtain cell growth curves.

\subsection{Statistical analysis}

The number of cells counted in the scanning electron micrographs, obtained in triplicate, is presented as mean \pm standard error of the mean. These data were compared by analysis of variance (ANOVA) complemented by the Tukey's test. The level of significance was $5 \%$ $(\mathrm{p} \leq 0.05)$.

\section{Results}

\subsection{Characterization of raw material powders}

The mean diameters of $10 \%, 50 \%$ and $90 \%$ volume $\left(\mathrm{d}_{90}, \mathrm{~d}_{50}, \mathrm{~d}_{10}\right.$, respectively), mean diameter size and specific surface area of the HAp and $\beta$-TCP powders are shown in Table 2. The particle size of both powders indicated a multimodal distribution and was narrower for HAp. The HAp and $\beta$-TCP powders had similar $\mathrm{d}_{50},(2.83$ and $2.67 \mathrm{~mm}$, respectively). The mean diameters of HAp and $\beta$-TCP were $3.6 \mathrm{~mm}$ and $4 \mathrm{~mm}$, respectively.

\subsection{Physical and chemical characterization}

The final density and roughness of calcium phosphate samples are shown in Figure 1. The final densities were about $93 \pm 3 \%$ of their theoretical densities. The densities

Table 2. Characteristics of HAp and $\beta$-TCP powders as raw materials for calcium phosphate ceramics.

\begin{tabular}{ccc}
\hline & HAp & $\beta$-TCP \\
\hline D 90\% $(\mu \mathrm{m})$ & 7.37 & 9.77 \\
D 50\% $(\mu \mathrm{m})$ & 2.83 & 2.67 \\
D 10\% $(\mu \mathrm{m})$ & 0.80 & 0.60 \\
Mean diameter size $(\mu \mathrm{m})$ & 3.59 & 4.0 \\
Specific surface area $\left(\mathrm{m}^{2} / \mathrm{g}\right)$ & $45.7 \pm 0.2$ & $2.3 \pm 0.1$ \\
\hline
\end{tabular}

of calcium phosphate samples increased slightly with HAp content in the mixture. All samples showed less than $10 \%$ residual porosity.

The roughness of pure samples, namely 100 HAp and TCP were higher, with 1.75 and $1.55 \mu \mathrm{m}$, respectively. The roughness of $50 \mathrm{HA}$ samples was lower and $\sim 1 \mathrm{~mm}$. The $25 \mathrm{HA}$ and $75 \mathrm{HA}$ samples had intermediate roughness. Overall, calcium phosphate samples with lower densities had higher surface roughness $\left(\mathrm{R}^{2}=0.98\right)$.

Data from XRD analysis (Figure 2a, b) showed the presence of either HAp or $\beta$-TCP in single phase sintered ceramics. The $50 \mathrm{HA}$ sample showed crystalline phases of both HAp and $\beta$-TCP. In the detail of the $30-35^{\circ}$ range XRD (Figure $2 b$ ), $\alpha$-TCP phase was not identified in all the samples. The other biphasic sintered ceramics also showed the two crystalline phases of calcium phosphate.

Typical SEM micrographs of surfaces of samples of calcium phosphate with different amounts of HAp and taken prior to the in vitro tests are shown in Figure 3 . The 100 HA sample showed higher level of densification than the other mixtures. Samples with more than $50 \% \beta$-TCP phase (Figure 3d, e) revealed grain growth. Residual porosity was also observed in these samples.

\subsection{Biological response}

Cell adhesion can be observed in the scanning electron micrographs of fibroblasts attached to ceramic substrates after 1 day of seeding (Figures 4 and 5). The overall morphology of the fibroblasts was similar in all groups showing stellate or fusiform aspects. Moreover, adherence of FMM1 cells was observed in samples from all groups. The cell monolayers were loose after one day of seeding. The high magnification SEM micrographs (Figure 5) reveal the overall cell morphology and cell extensions on the ceramic sample surface.

Cell proliferation can be observed by comparing the different scanning electron micrographs with fibroblasts attached to the ceramic substrates after 2 and 3 days of seeding (Figure 6 and 7). The cell monolayer was denser after 3 days (Figure $6 \mathrm{f}-\mathrm{j}$ ). There were no marked differences in the distribution of cells on the top surface of samples from the different groups until 2 days after seeding. After longer times the cell density was higher and the cells had

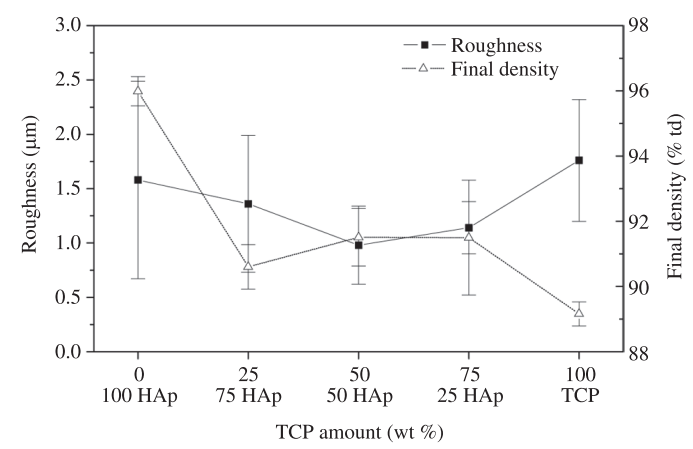

Figure 1. Final density (\% theoretical) and roughness $(\mu \mathrm{m})$ of HAp/TCP samples. 
more extensions. At the end of the study period (3 days), the samples made of TCP were completely covered by a cell monolayer (Figure 6f), whereas samples from the other groups still revealed areas devoid of cells.

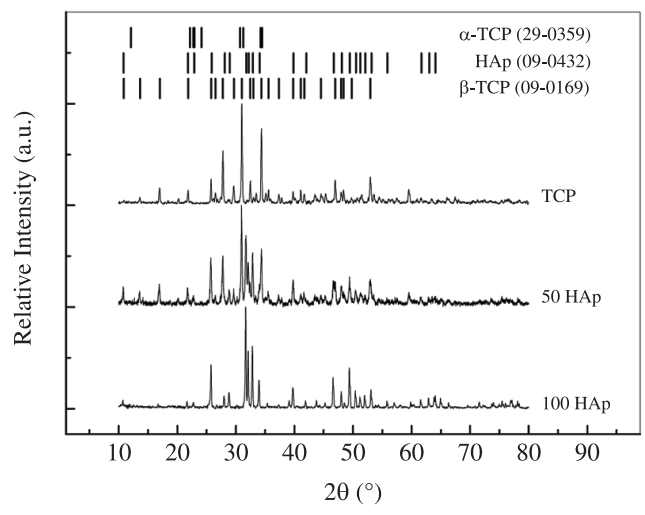

(a)
Figure 8 shows graphically the number of FMM1 cells adhered to and proliferated on ceramic sample surfaces as a function of time (1,2 and 3 days). The number of cells increased significantly, independent of the experimental

Figure 2. X ray diffraction patterns of sintered HAp, TCP and 50 HAp samples: a) whole $10-60^{\circ}$ range; b) detail of $30-35^{\circ}$ range.

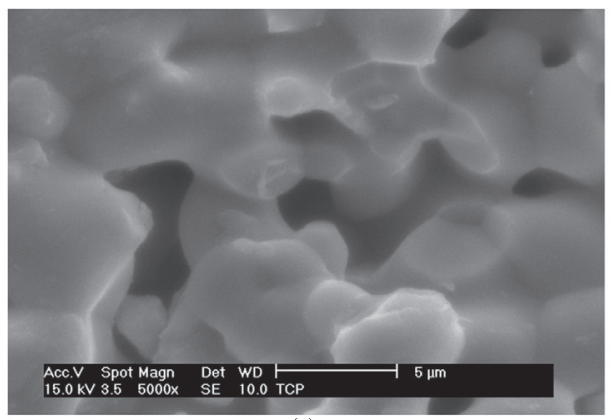

(a)

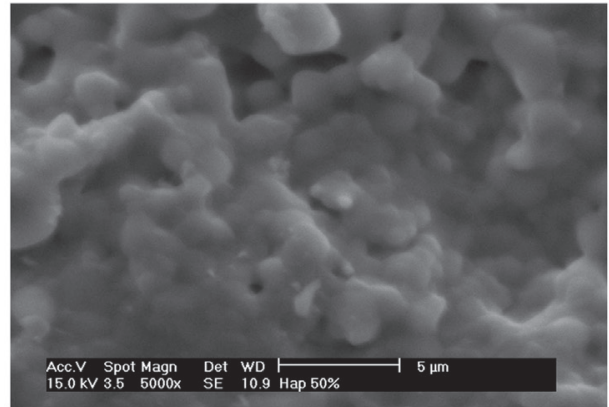

(c)

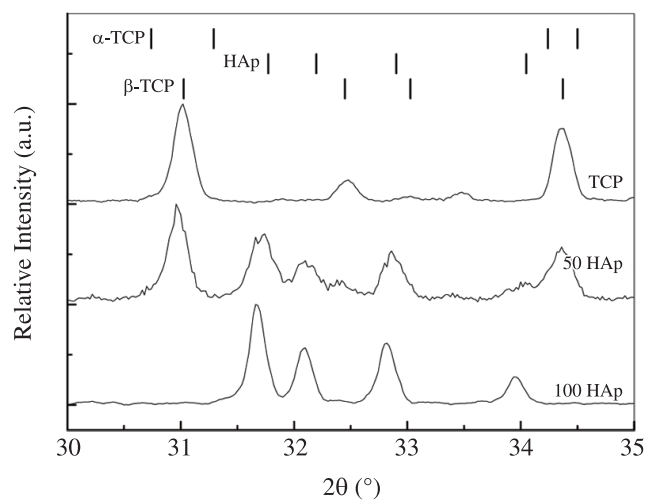

(b)

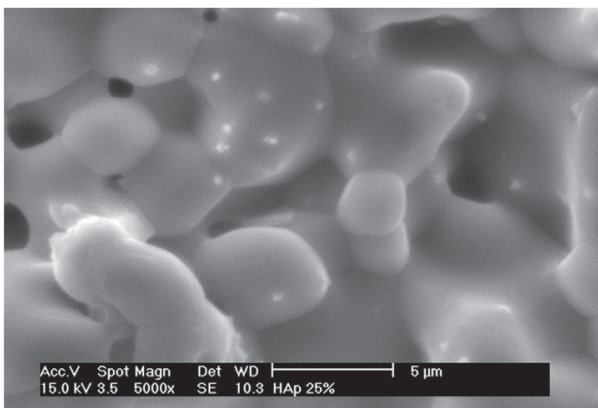

(b)

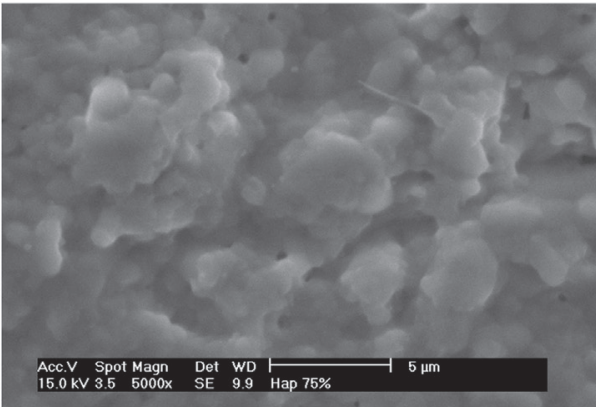

(d)

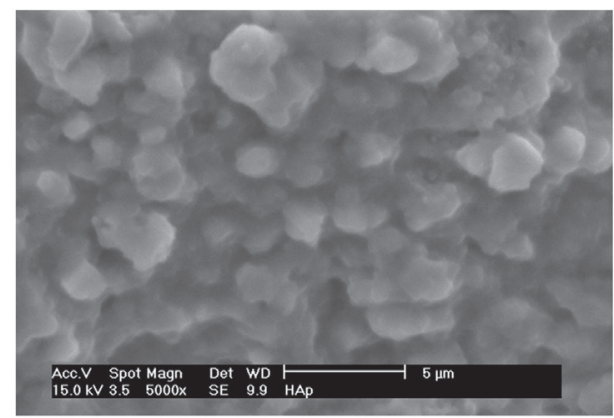

(e)

Figure 3. Scanning electron micrographs of calcium phosphate samples surface before cell culture experiments: a) TCP; b) 25 HAp; c) $50 \mathrm{HAp}$;) $75 \mathrm{HAp}$; e) $100 \mathrm{HAp}$. 


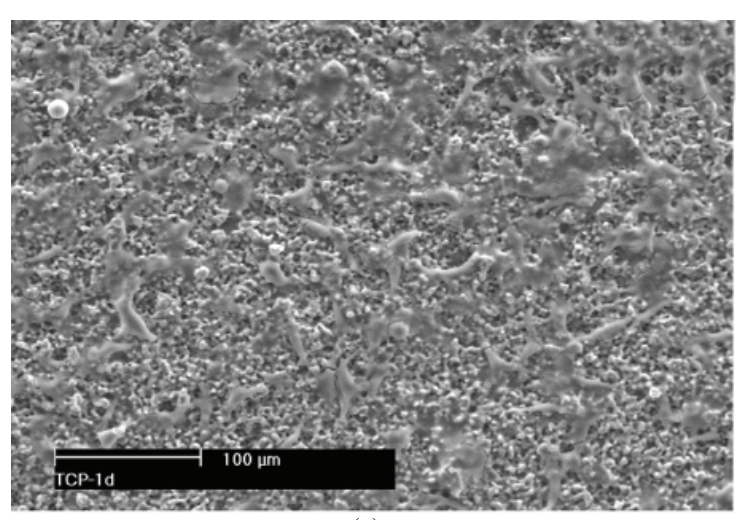

(a)

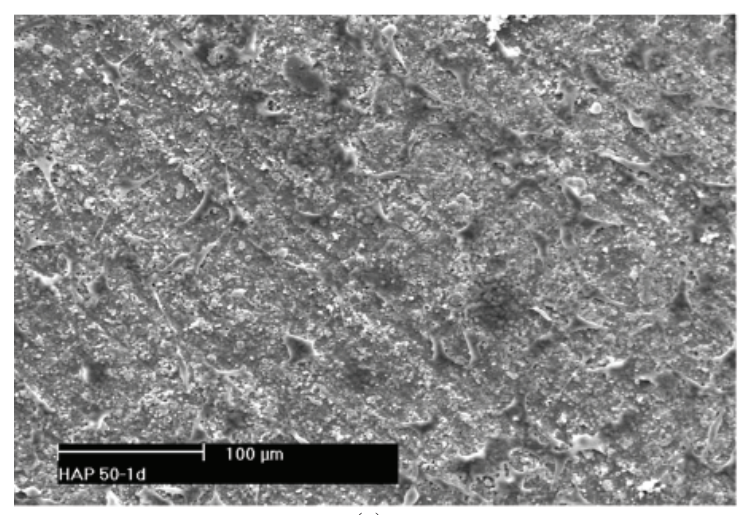

(c)

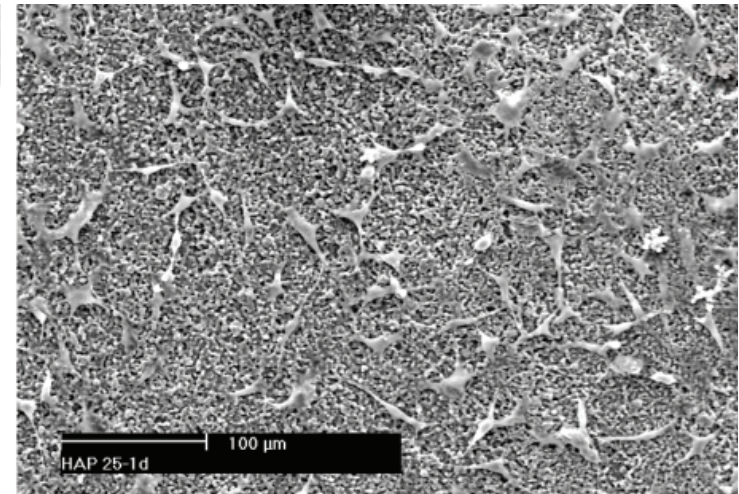

(b)

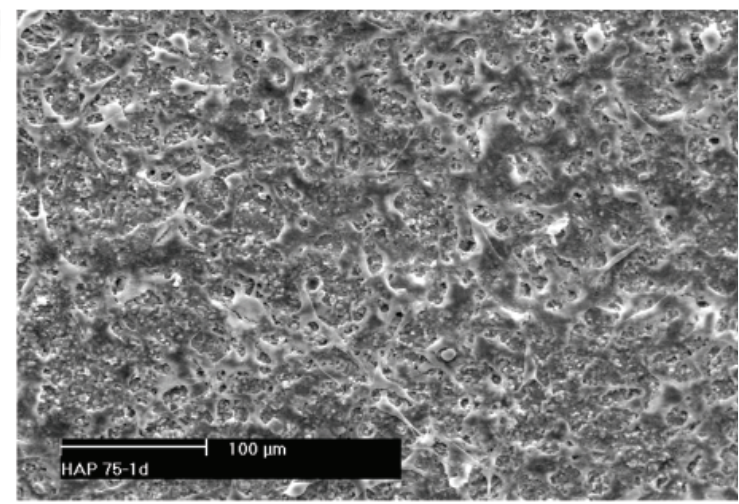

(d)

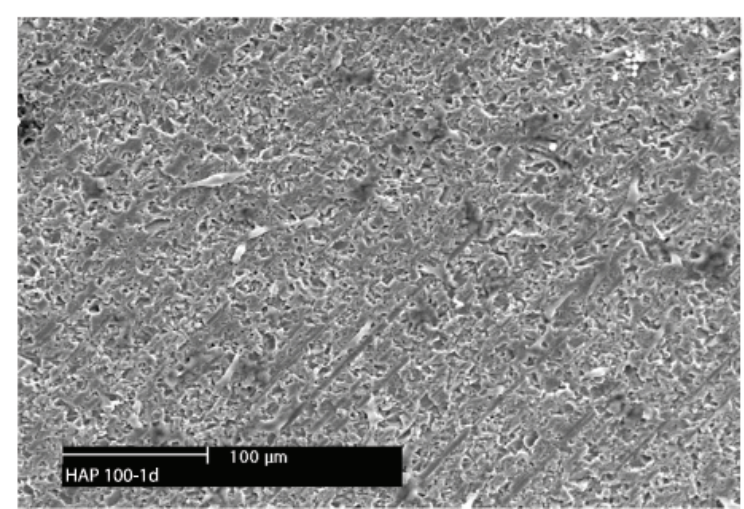

(e)

Figure 4. Scanning electron micrographs of FMM1 cells grown on sintered HAp/TCP ceramic substrates after 1 day cell culture. a) TCP; b) 25 HAp; c) 50 HAp; d) 75 HAp; e) 100 HAp.

group $(\mathrm{p} \leq 0.05)$ from the beginning till the end of the test. On day one, there was a significant increase in the number of adhered cells to the top of TCP and 25HA disks, compared with that adhered to 100 HA disks $(\mathrm{p}<0.01)$. Disks with more than $50 \%$ of HAp revealed significantly fewer cells than TCP $(\mathrm{p}<0.05)$. After three days, the TCP group revealed many more cells than all other groups $(\mathrm{p}<0.05)$. Amongst the other groups, 25HA showed more cells than all other groups, except the TCP $(\mathrm{p}<0.05)$.

\section{Discussion}

Search for bone substitute materials is an ongoing challenge. The composition and topography of these materials is of importance to determine its biological response. A common clinical situation that periodontists encounter is fixing of bone defects and this often requires the use of bone substitute materials. These materials include calcium phosphate based ceramics such as hydroxyapatite (HAp) and $\beta$-tricalcium phosphate ( $\beta$-TCP).

Characterization of raw calcium phosphate powders, including particle size distribution, was done because this information is essential to define the processing conditions to obtain crystalline ceramics of HAp, $\beta$-TCP or a mixture of these, without phase transformation and with desirable densities. Samples of these ceramics were sintered under different conditions in achieve similar final densities. The 


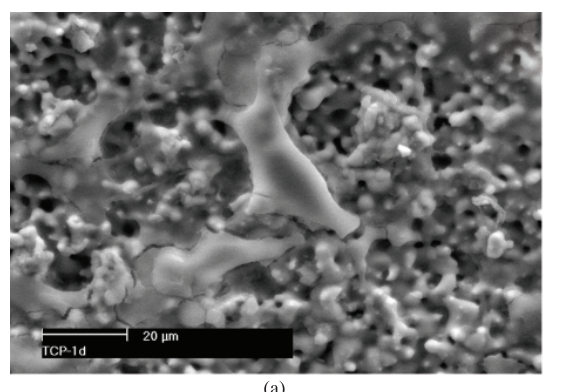

(a)

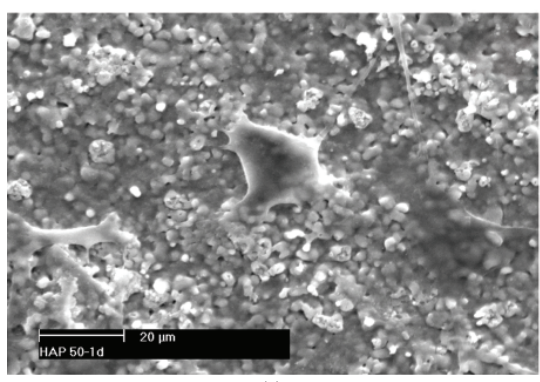

(c)

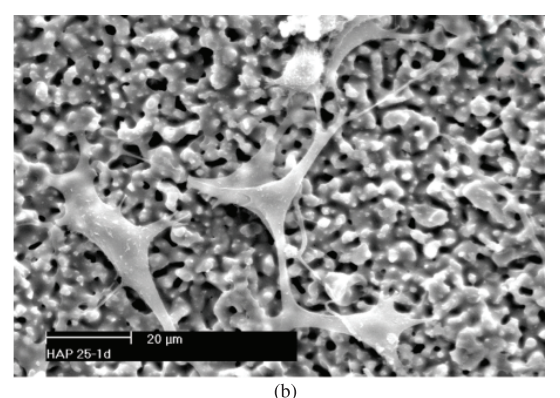

(b)

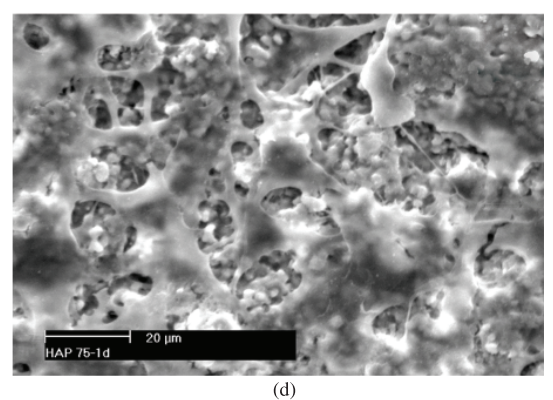

(d)

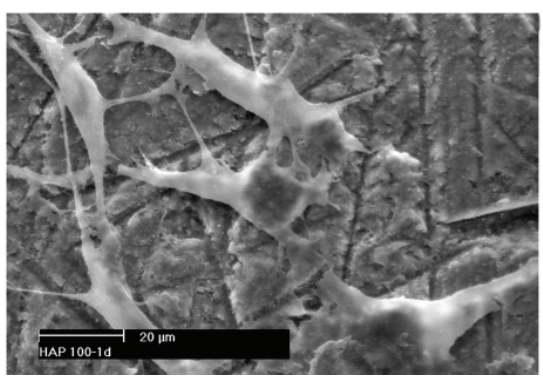

(e)

Figure 5. Scanning electron micrographs (in detail) of FMM1 cells grown on sintered HAp/TCP ceramic substrates after 1 day cell culture. a) TCP; b) 25 HAp; c) 50 HAp; d) 75 HAp; e) 100 HAp.

higher temperature used to sinter our calcium phosphate ceramics with more than 50\% $\beta$-TCP phase lead to grain growth, even though the raw materials had similar particle size distribution. Moreover, the final densities that were attained (about $93 \%$ of the theoretical densities) gave the samples adequate microporosity to drain fluid, enabling thus, the dissolution/precipitation process ${ }^{1}$. Since physical and chemical properties of biomaterial surfaces play an important role in osteointegration ${ }^{10,26}$, initially the physical characteristics of the calcium ceramic materials were determined, focusing on composition, surface roughness and the microstructure.

The composition and surface roughness of calcium phosphate based ceramic are important to predict interfacial behavior at the material/tissue interface and its interaction with the biological environment ${ }^{27}$. It has been shown that smooth surfaces are suitable for soft tissues, both for anchoring and growth of fibroblasts ${ }^{28,29}$, However, roughened calcium phosphate implant surfaces have better bone deposition compared with polished surfaces ${ }^{30}$. Surface roughness influences cell alignment ${ }^{31,32}$, orientation and migration. These aspects are important in several bone formation stages, including adhesion, proliferation, differentiation, synthesis of bone matrix, maturation and calcification of tissue on the material's surface ${ }^{27,33-35}$. Another important factor affecting initial cell adhesion is the presence of specific phases, as several authors have suggested that adhesion takes place only after the dissolution process $^{1,36}$. TCP samples were more soluble, had higher surface roughness and the lowest density. These features lead to faster cell growth compared to samples containing HAp. In fact, higher amounts of HAp in the ceramic led to higher density, lower roughness and decreased solubility. Consequently, the number of cells attached to the surface of these ceramics was always lesser than those on TCP samples.

Thus, the higher biocompatibility of the TCP samples could be attributed not only to its physical characteristics but also to its dissolution behavior. The $\beta$-TCP dissolved faster, compared to $\mathrm{Hap}^{1,2}$ and this aspect could have induced micro-roughness by diffusion of surface ions, and increased fluid drain. The SEM micrographs corroborate this observation and revealed higher porosity in TCP samples, which probably resulted in a surface texture more propitious for cell adhesion. In in vivo conditions, these micropores can act as fluid drains, supplying nutrients to 


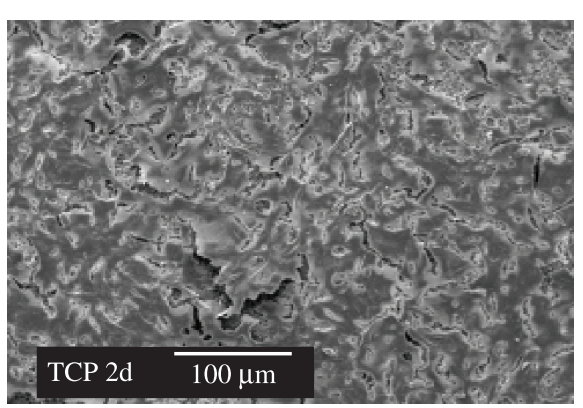

(a)

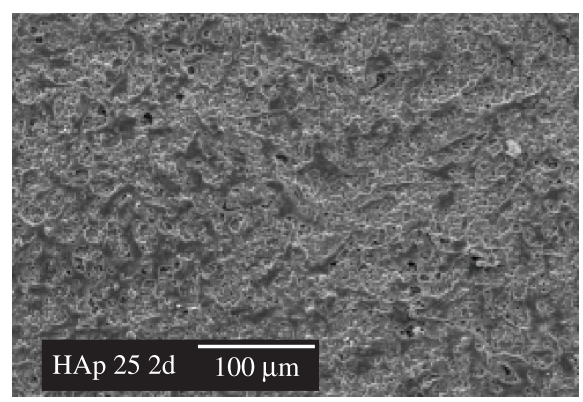

(b)

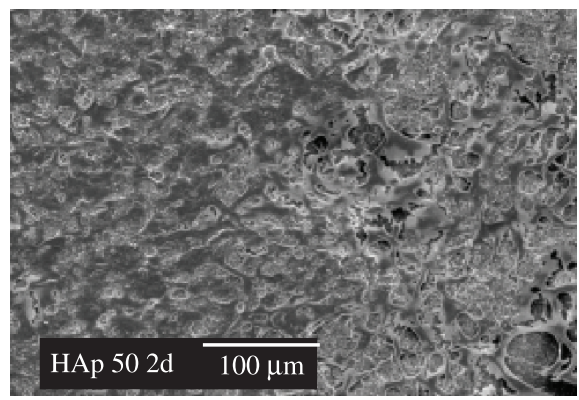

(c)

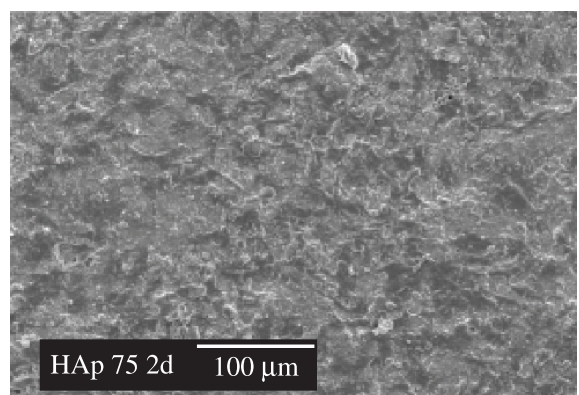

(d)

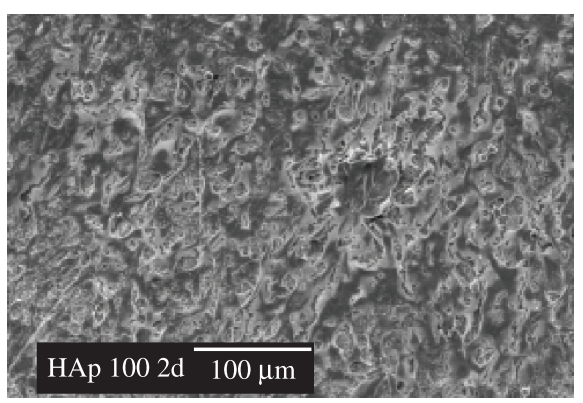

(e)

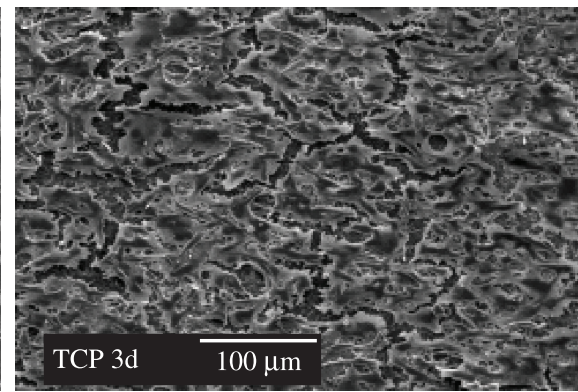

(f)

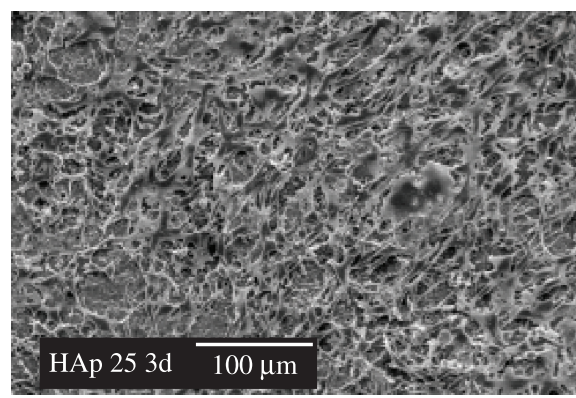

$(\mathrm{g})$

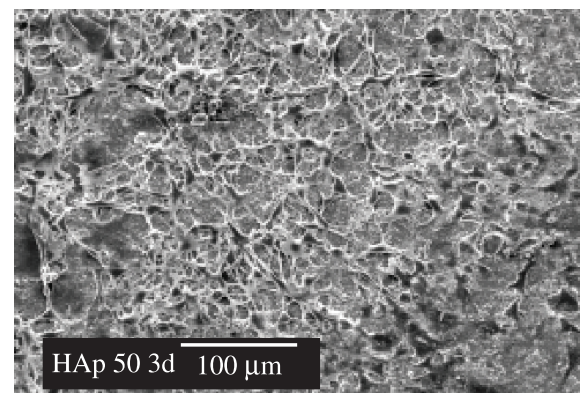

(h)

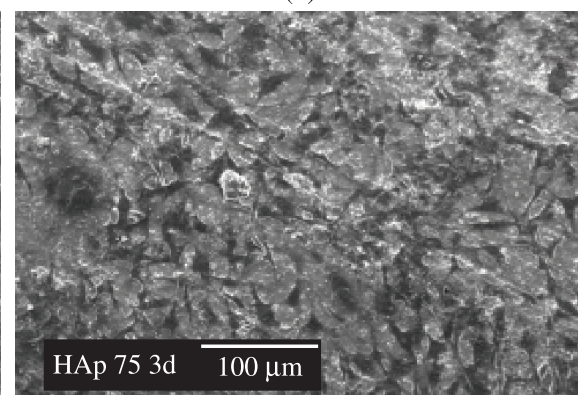

(i)

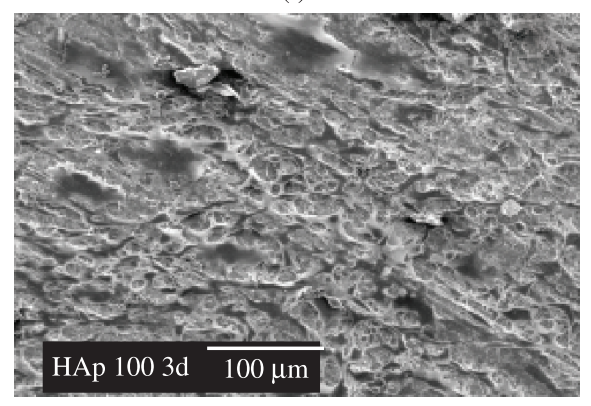

(j)

Figure 6. Scanning electron micrographs of FMM1 cells grown on sintered HAp/TCP ceramic substrates after 2 and 3 days cell culture. Left column: 2 day exposure; right column: 3 days exposure. $1_{\mathrm{st}}$ line: TCP; $2_{\text {nd }}$ line: $25 \mathrm{HA} ; 3_{\mathrm{rd}}$ line: $50 \mathrm{HA} ; 4_{\mathrm{th}}$ line: $75 \mathrm{HA} ; 5_{\mathrm{th}}$ line: $100 \mathrm{HAp}$. 


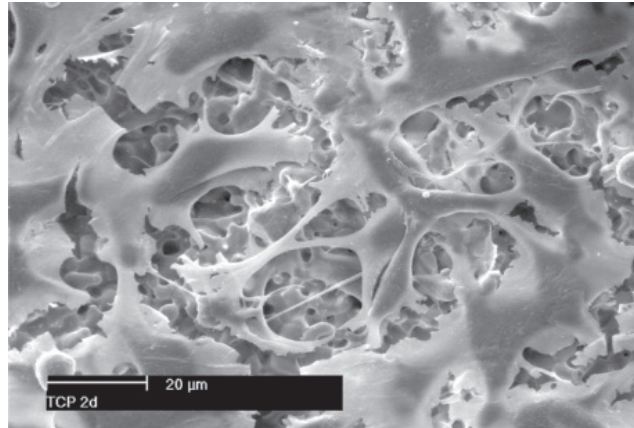

(a)

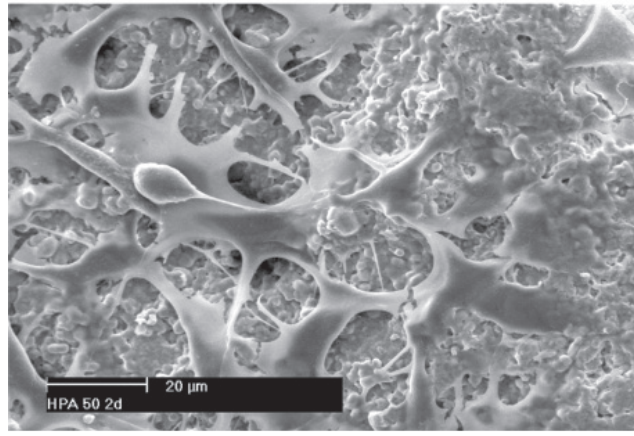

(c)

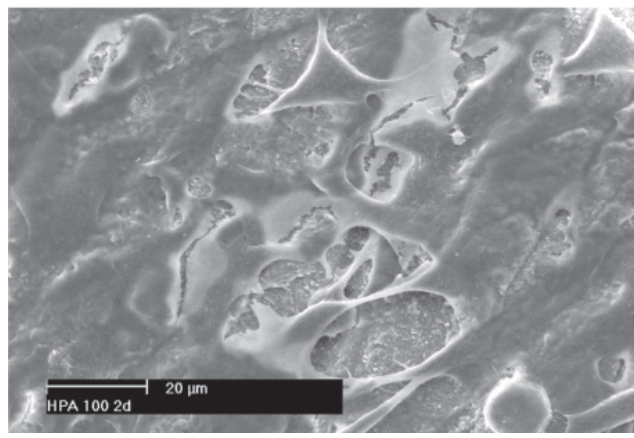

(e)

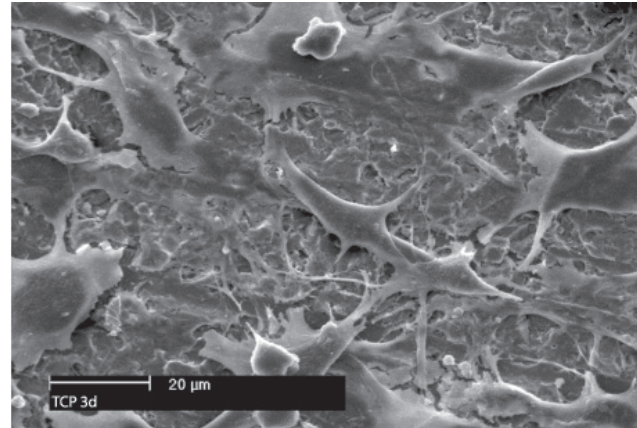

(b)

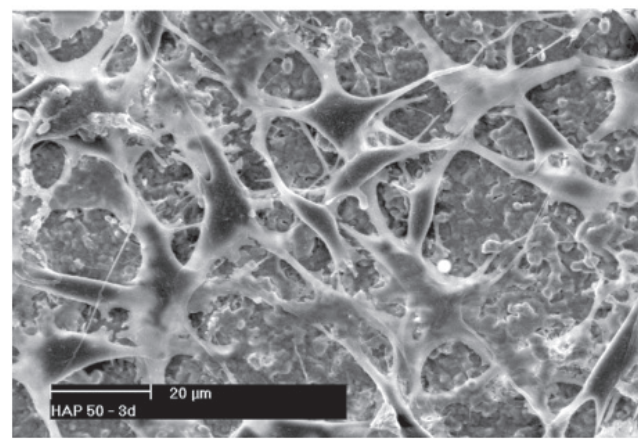

(d)

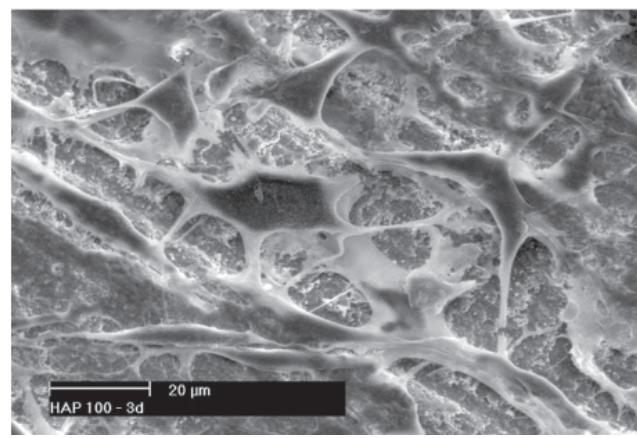

(f)

Figure 7. Scanning electron micrographs (in detail) of FMM1 cells grown on sintered HAp/TCP ceramic substrates after 2 and 3 days cell culture. Left column: 2 day exposure; right column: 3 days exposure. $1_{\mathrm{st}}$ line: TCP; $2_{\mathrm{nd}}$ line: 50 HA; $3_{\mathrm{rd}}$ line: 100 HAp.

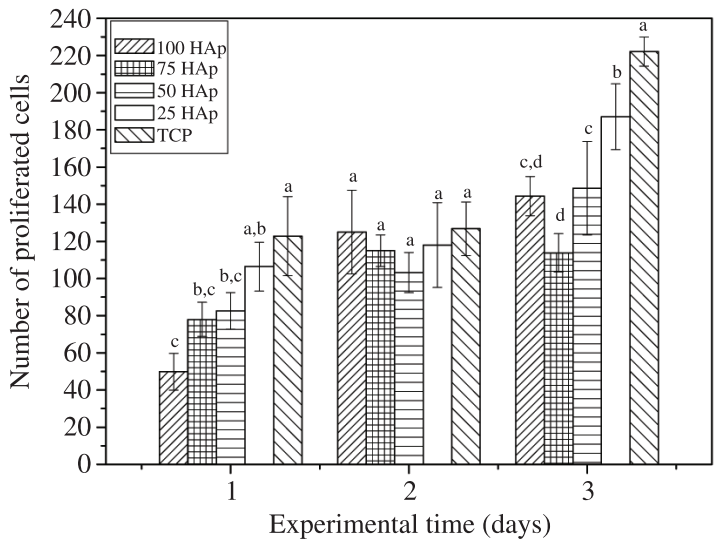

Figure 8. FMM1 cell growth on HAp/TCP ceramic substrates as a function of different cell exposure time. Different letters mean that the values are statistically different, for the same exposure time. the neoformed tissue 37,38 . Hence, solubility of TCP is an important parameter to increase its biocompatibility.

Based in the results of this study we conclude that as a bone substitute material, the TCP ceramic has a faster biological response. Even though TCP does not exhibit bioactive characteristics of HAp ceramic, it is bioresorbable, has the density and roughness that make it have higher cell adhesion and proliferation. This in turn indicates that this material (TCP) is a better bone substitute. Even though biphasic ceramics are considered to be more bioactive, TCP ceramics are capable of inducing faster responses at the initial stages, suggesting that calcium phosphate based ceramics with a $\mathrm{Ca} / \mathrm{P}$ concentration gradient can be more suitable for use as implant materials. A surface layer of TCP can further accelerate the osteointegration process and improve the fields of application of these ceramics. In general, the experiments reported in the literature have 
been carried out for longer periods, without attention to the initial stages.

\section{Conclusions}

The composition, expressed as $\mathrm{Ca} / \mathrm{P}$ ratio, influenced the biological behavior of several sintered calcium phosphate ceramics that were tested in vitro for short periods. Lower $\mathrm{Ca} / \mathrm{P}$ ratio enhanced biocompatibility. As a result, the TCP sample had higher surface roughness and lower density, induced thereby higher cell viability with increased initial reactivity. These attributes indicate that ceramics with a $\mathrm{Ca} / \mathrm{P}$

\section{References}

1. Daculsi G. Biphasic calcium phosphate concept applied to artificial bone, implant coating and injectable bone substitute. Biomaterials. 1998; 19(16):1473-1478. http://dx.doi. org/10.1016/S0142-9612(98)00061-1

2. Legeros RZ. Calcium Phosphates in Oral Biology and Medicine. Monographs in Oral Science. 1999; 15:1-201.

3. Wang L and Nancollas GH. Calcium orthophosphates: crystallization and dissolution. Chemical Reviews. 2008; 108(11):4628-4669. PMid:18816145 PMCid:2743557. http://dx.doi.org/10.1021/cr0782574

4. Garrido CA, Lobo SE, Turíbio FM and Legeros RZ. Biphasic calcium phosphate bioceramics for orthopaedic reconstruction: clinical outcomes. International Journal of Biomaterials. 2011. Article ID 129727. PMid:21760793 PMCid:3132521. http:// dx.doi.org/10.1155/2011/129727

5. Coelho MJ, Trigo Cabral A and Fernandes MH. Human bone cell cultures in biocompatibility testing. Part I: osteoblastic differentiation of serially passaged human bone marrow cells cultured in $\alpha$-MEM and in DMEM. Biomaterials. 2000; 21(11): 1087-1094. http://dx.doi. org/10.1016/S0142-9612(99)00284-7

6. Langstaff S, Sayer M, Smith TJN and Pugh SM. Resorbable bioceramics based on stabilized calcium phosphates. Biomaterials. 2001; 22(2):135-150. http://dx.doi.org/10.1016/ S0142-9612(00)00139-3

7. Daculsi G, Laboux O, Malard O and Weiss P. Current state of the art of biphasic calcium phosphate bioceramics. Journal of Materials Science: Materials in Medicine. 2003; 14(3):195-200. PMid:15348464. http://dx.doi.org/10.1023/A:1022842404495

8. Rangavittal N, Landa-Cánovas AR, González-Calbet JM and Vallet-Regi M. Structural study and stability of hydroxyapatite and $\beta$-tricalcium phosphate: two important bioceramics. Journal of Biomedical Materials Research. 2000; 51(4):660-668. http:// dx.doi.org/10.1002/1097-4636(20000915)51:4\%3C660::AIDJBM14\%3E3.0.CO;2-B

9. Daculsi G and LeGeros R. Biphasic calcium phosphate (BCP) bioceramics: Chemical, physical and biological properties. In: Wnek GE and Bowlin GL. Encyclopedia of Biomaterials and Biomedical Engineering. 2nd ed. New York: Marcel Dekker; 2006. chap. 34, p. 1-9.

10. Xin R, Leng Y, Chen J and Zhang Q. A comparative study of calcium phosphate formation on bioceramics in vitro and in vivo. Biomaterials. 2005; 26(33):6477-6486. PMid:15992923. http://dx.doi.org/10.1016/j.biomaterials.2005.04.028

11. Marchi J, Ribeiro C and Bressiani AHA. Interaction study of calcium phosphate ceramics in cell culture medium: in vitro studies. Unsubmitted paper, waiting review process. concentration gradient can be used as an implant. The best calcium phosphate ceramic implant seems to be TCP coated $\mathrm{BCP}$ for quicker osteointegration.

\section{Acknowledgments}

The authors thank Marilene M. Targino and Bruno B Silva for their help with the experiments. The SEM evaluations were done by Celso Vieira and Nildemar Ferreira from IPEN/CCTM, for which the authors are grateful. The authors acknowledge the financial support of $\mathrm{CNPq}$ and FAPESP.

12. Ayers R, Nielsen-Preiss S, Ferguson V, Gotolli G, Moore JJ and Kleebe HJ. Osteoblast-like cell mineralization induced by multiphasic calcium phosphate ceramic. Materials Science and Engineering C. 2006; 26(8):1333-1337. http://dx.doi. org/10.1016/j.msec.2005.08.028

13. Li X, van Blitterswijk CA, Feng Q, Cui F and Watari F. The effect of calcium phosphate microstructure on bone-related cells in vitro. Biomaterials. 2008; 29(23):3306-3316. PMid:18485476. http://dx.doi.org/10.1016/j.biomaterials.2008.04.039

14. Ducheyne P and Qiu Q. Bioactive ceramics: the effect of surface reactivity on bone formation and bone cell function. Biomaterials. 1999; 20(23-24):2287-2303. http://dx.doi. org/10.1016/S0142-9612(99)00181-7

15. Vandiver J, Dean D, Patel N, Bonfield W and Ortiz C. Nanoscale variation in surface charge of synthetic hydroxyapatite detected by chemically and spatially specific high-resolution force spectroscopy. Biomaterials. 2005; 26:271-283. PMid:15262469. http://dx.doi.org/10.1016/j.biomaterials.2004.02.053

16. Rakovan J. Growth and surface properties of apatite. Reviews in Mineralogy and Geochemistry. 2002; 48(1):51-86. http:// dx.doi.org/10.2138/rmg.2002.48.3

17. Nancollas GH and Wu W. Biomineralization mechanisms: a kinetics and interfacial energy approach. Journal of Crystal Growth. 2000; 211(1-4):137-142. http://dx.doi.org/10.1016/ S0022-0248(99)00816-7

18. Parfitt GD and Rochester CH. Adsorption from solution at the solid/liquid interface. London: Academic Press; 1983.

19. Ribeiro C, Rigo ECS, Sepúlveda P, Bressiani JC and Bressiani AHA. Formation of calcium phosphate layer on ceramics with different reactivities. Materials Science and Engineering C. 2004; 24(5):631-636. http://dx.doi. org/10.1016/j.msec.2004.08.006

20. Chiang YM, Birnie DP and Kingery WD. Physical ceramics: principles for ceramic science and engineering. 3th ed. New York: John Willey and Sons; 1997.

21. American Society for Testing and Materials - ASTM. C20-00: Standard Test Methods for Apparent Porosity, Water Absorption, Apparent Specific Gravity, and Bulk Density of Burned Refractory, Brick and Shapes by Boiling Water. ASTM; 2005

22. Marchi J, Delfino CS, Bressiani JC, Bressiani AHA and Marques MM. Cell Proliferation of Human Fibroblasts on Alumina and Hydroxyapatite-Based Ceramics with Different Surface Treatments. International Journal of Applied Ceramic Technology. 2010; 7(2):139-147. http://dx.doi.org/10.1111/ j.1744-7402.2009.02388.x

23. Marchi J, Ussui V, Delfino CS, Bressiani AHA and Marques MM. Analysis in vitro of the cytotoxicity of potential implant 
materials. I: Zirconia-titania sintered ceramics. Journal of Biomedical Materials Research: Part B. 2010; 94B(2):305-311.

24. International Organization for Standardization - ISO. ISO 10993-5: Biological Evaluation of Medical Devices. Part 5: Tests for in vitro cytotoxicity. Genève: ISO; 2009.

25. Wilcox D, Dove B, McDavid D and Greer D. Image Tool for Windows. version 3.0. San Antonio: University of Texas Health Science Center in San Antonio; 1995-2002.

26. Weiner S and Dove PM. An overview of biomineralization processes and the problem of the vital effect. Journal of the Mineralogical Society of America. 2003; 54(1):1-29. http:// dx.doi.org/10.2113/0540001

27. Daculsi G. Physicochemical and ultrastructural analysis of bone bioactive interface. Biomaterial Tissue Interaction. 1992; 10:296-304.

28. Jones FH. Teeth and bones: application of Surface Science to dental materials and related biomaterials. Surface Science Reports. 2001; 42(3-5):75-205. http://dx.doi.org/10.1016/ S0167-5729(00)00011-X

29. Boskey AL and Roy R. Cell culture systems for studies of bone and tooth mineralization. Chemical Reviews. 2008; 108(11):4716-4733. PMid:18800815 PMCid:2653100. http://dx.doi.org/10.1021/cr0782473

30. Nakae H, Inui R, Hirata Y and Saito H. Effects of surface roughness on wettability. Acta Materialia. 1998; 48(7):2313-2318. http:// dx.doi.org/10.1016/S1359-6454(97)00387-X

31. Chehroudi B, McDonnell D and Brunette DM. The effects of micromachined surfaces on formation of bonelike tissue on subcutaneous implants as assessed by radiography and computer image processing. Journal of Biomedical Materials Research. 1998; 34(3):279-290. http://dx.doi.
org/10.1002/(SICI)1097-4636(19970305)34:3\%3C279::AIDJBM2\%3E3.0.CO;2-H

32. Buser D, Schenk RK, Steinemann S, Fiorellini JP, Fox CH and Stich $\mathrm{H}$. Influence of surface characteristics on bone integration of titanium implants. A histomorphometric study in miniature pigs. Journal of Biomedical Materials Research. 1991; 25(7):889-902. PMid:1918105. http://dx.doi. org/10.1002/jbm.820250708

33. Fisher JP and Reddi AH. Functional Tissue Engineering of Bone: Signals and Scaffolds. In: Ashammakhi N and Ferretti P, editors. Topics in Tissue Engineering. 1st ed. University of Oulu; 2003. II Bone. E-book.

34. Myers D. Surfaces, interfaces and colloids: principles and applications. 2nd ed. New York: Wiley; 1999. http://dx.doi. org/10.1002/0471234990

35. Cazalbou S, Combes C, Eichert D and Rey C. Adaptive physico-chemistry of bio-related calcium phosphates. Journal of Materials Chemistry. 2004; 14:2148-2153. http://dx.doi. org/10.1039/b401318b

36. Basle M, Chappard D, Grizon F, Filmon R, Delectrin J, Daculsi $\mathrm{G}$ et al. Osteoclastic resorption of $\mathrm{CaP}$ biomaterials implanted in rabbit bone. Calcified Tissue International. 1993; 53(5):348-356. PMid:8287324. http://dx.doi.org/10.1007/BF01351842

37. Raffaini $G$ and Ganazzol F. Sequential adsorption of proteins and the surface modification of biomaterials: A molecular dynamics study. Journal of Materials Science: Materials in Medicine. 2007; 18(2)309-316. PMid:17323163. http://dx.doi. org/10.1007/s10856-006-0694-5

38. Sánchez-Salcedo S, Balas F, Izquierdo-Barba I and Vallet-Regí $M$. In vitro structural changes in porous $\mathrm{HA} / \beta$-TCP scaffolds in simulated body fluid. Acta Biomaterialia. 2009; 5(7):2738-2751. PMid:19394904. http://dx.doi.org/10.1016/j.actbio.2009.03.025 